\title{
Die dilemma van die musiekwetenskaplike in die onderrigsituasie
}

\author{
Bertha Spies \\ Departement Musiek \\ Potchefstroomse Universiteit vir Christelike Hoër Onderwys \\ POTCHEFSTROOM
}

\begin{abstract}
The dilemma of the musicologist who is also a teacher

In this article a main educational objective, namely the interpretation of reality, forms the basis for discussing the dilemma of the musicologist who is also a teacher. Firstly, various facets of musical reality are discussed under the following headings: the meaning of reality for the musicologist, artistic representation of reality and an idealized musical reality. Secondly, the manner in which musical reality is interpreted is discussed. Thirdly, results of a fragmented musical reality are mentioned and finally, proposals aimed at solving the problem of the musicologist-teacher are put forward, arguing for a more objective view of reality as a whole, stressing the double responsibility of the musicologist-teacher to interpreting difficult texts and the necessity to re-evaluate traditional theories in the light of their didactic effectiveness.
\end{abstract}

\section{Inleiding}

In Suid-Afrika is dit vir ' $n$ musiekwetenskaplike omtrent onmoontlik om net uit navorsing ' $n$ bestaan te maak. Indien ' $n$ musikus in 'n akademiese rigting wil spesialiseer, beteken dit dus dat hy ook onderrig sal moet gee. Dit is egter nie net in ons land waar akademiese poste aan onderrig gekoppel word nie. "We all teach ..." skryf William Thompson (1987:345), professor in musiekteorie aan die Universiteit van Suid-Kalifornië. Om te verseker dat die akademiese tradisie voortgesit word, is dit noodsaaklik dat die inhoud van 'n vak effektief oorgedra word en om hierdie doelstelling te bereik moet rekening gehou word met die doelstellings van die opvoedkunde.

Die versoening van musiekwetenskaplike en opvoedkundige doelstellings is egter om verskeie redes ' $n$ probleem, soos in hierdie artikel aangetoon sal word. 'n Hoofdoelstelling van die opvoedkunde, naamlik dat die opvoedkunde gemik 
is op die ontsluiting van die werklikheid (Van der Stoep \& Louw, 1990:35), word as uitgangspunt geneem.

Eerstens sal verskeie fasette van die musiekwerklikheid bespreek word, tweedens sal probleme rondom die ontsluiting van die musiekwerklikheid onder oë geneem word, derdens sal die gevolge van die wyse van ontsluiting bespreek word en laastens sal voorstelle gemaak word wat daarop gemik is om nuwe perspektiewe insake die musiekwetenskaplike wat in 'n onderrigsituasie staan, daar te stel.

\section{Die musiekwerklikheid}

\subsection{Wat beteken die werklikheid vir die musiekwetenskap- like?}

Een van die belangrikste take van die opvoedkundige, en dus ook van die musiekwetenskaplike wat in 'n onderrigsituasie staan, is dat hy die werklikheid vir die leerder moet ontsluit. Vir die musiekwetenskaplike is hierdie opdrag egter 'n probleem omdat hy homself moeilik versoen met die volle implikasie van die begrip werklikheid wanneer dit op die musiek betrekking het. Aan die een kant dui die musiekwerklikheid op kommersiële en ligte musiek wat ons daagliks hoor en aan die ander kant dui dit op hedendaagse kunsmusiek wat feitlik nooit gehoor word nie, hoewel die komponiste daarvan daarop roem dat hulle die werklikheid weergee soos hulle dit beleef.

Dit is vir die musiekwetenskaplike baie moeilik om te aanvaar dat die musiek waarmee hy homself besig hou, nie vir die algemene publiek ' $n$ werklikheid is nie. Marknavorsing wat van 1986 tot 1987 in Suid-Afrika gedoen is (Heimes, 1989:9) het aangedui dat die persentasie radioluisteraars wat in die betrokke periode na Westerse kunsmusiek geluister het, hoogstens $2,8 \%$ was. Navorsing wat in 1993 in die VSA onderneem is (Time Magazine, 1995:49), het soortgelyke resultate opgelewer. In 'n ondersoek na die verkope van musiekopnames het rock-musiek, met 'n uitslag van 32,6\% van die totale verkope, die beste gevaar terwyl die verkope van "klassieke" musiekopnames slegs $4 \%$ van die totale verkope verteenwoordig het. Al kan twyfel bestaan oor die geldigheid van marknavorsingsmetodes en dus ook oor die resultate van sulke ondersoeke, is dit duidelik dat die uitslae van hierdie twee ondersoeke negatiewe implikasies het vir enige persoon wat gemoeid is met "klassieke" musiek. Ten spyte van dringende uitsprake oor die implikasie van "ligte musiek" vir die musiekprofessie (Lüdemann, 1994:124-125), skram baie musiekwetenskaplikes weg van die realiteit dat musiek vir die meeste mense verwys na kommersiële musiek en popmusiek. 
In teenstelling met hierdie siening van die werklikheid word die sogenoemde "kunsmusiek" van vandag weer deur die komponiste daarvan beskou as hulle siening van die werklikheid. Hierdie musiek word egter glad nie deur die breë publiek aanvaar nie. Selfs baie opgeleide musici vind hierdie musiek ontoeganklik en onverstaanbaar (Reitan, 1992:626).

Die gevolg van hierdie polêre sienings van die musiekwerklikheid is dat die musiekwetenskaplike geneig is om die musiek van die verlede as (enigste?) werklikheid te beskou. Hier word meer spesifiek verwys na die musiek van die agtiende en die negentiende eeu - die komposisies van die sogenoemde "groot meesters" Bach, Haydn, Mozart, Beethoven, Chopin, ensovoorts. Die statiese geaardheid van hierdie oorgelewerde tradisie het mettertyd deel van die musiekkanon geword. Geoffrey Chew (1992:3), verbonde aan die Royal Holloway and Bedford New College in London, verwys ook na die onkritiese oorlewering van tradisie wanneer hy vra "... why such an important position in the modern musical canon should be occupied by instrumental compositions by German masters of the eighteenth century?"

Polansky, redakteur van Leonardo Music Journal, tydskrif van die Internasionale Vereniging vir Kuns, Wetenskap en Tegnologie, verwys in die bekendstellingsuitgawe ook na die verskynsel om die musiek van die verlede te kanoniseer: "We are ready to canonize the most obscure, long-gone parts of our 'tradition', while ignoring equally rich (often richer) and important other living 'traditions'" (Polansky, 1991:17). In sy bespreking het hy spesifiek verwys na die standaardpraktyk om sestiende-eeuse kontrapunt te bestudeer.

Hierdie "leef in die verlede" kan gesien word as 'n soort ontsnappingskultuur. Die musiek van die verlede, meer spesifiek tonale musiek, is vir die luisteraar "mooi" omdat dit onmiddellik verstaanbaar is. Enige musiek wat 'n mate van intellektuele persepsie verg, soos musiek van die twintigste eeu, word afgemaak as "lelik", "wanklankig", "dit maak nie sin nie", ensovoorts (Mitchell, 1963:20).

Die ontoeganklikheid van hedendaagse kunsmusiek is geleë in 'n persepsie wat deur kondisionering veroorsaak is. Van kleins af hoor kinders slegs tonale musiek. Wanneer hulle leer om musiek te speel of te sing, is dit feitlik net tonale musiek. Dit beteken dat musiek waarvan die ordeningsbeginsels afwyk van die ordeningsbeginsels van tonale musiek, as onreëlmatig geïnterpreteer word. Aangesien die eerste kennismaking met nuwe musiek gewoonlik op die ouditiewe vlak lê, is die "normale" gewaarwording by die aanhoor van hierdie musiek, wat breedweg as nie-tonale musiek beskryf word, dat daar geen samehang is nie, dat dit gevolglik onverstaanbaar is, of selfs "vals" klink. Dit is 'n ernstige aanklag teen die musiekonderrigprofessie dat jongmense sonder 
Die dilemma van die musiekwetenskaplike in die onderrigsituasie

musiekopleiding dikwels meer geneë is om nuwe musiek te aanvaar as jongmense wat musiek "bestudeer" het.

Die vraag is nou tot watter mate die musiekwetenskaplike verbind is tot die voortsetting van die "groot meesters"-kanon? Word navorsing en die opleiding van musiekstudente net daarop gerig om bestaande persepsies ten opsigte van "standaardwerke" voort te sit of het die musiekwetenskaplike 'n verantwoordelikheid om ook die musiek van ons tyd te ontsluit? Baie musici weet nie eers hoe klink kunsmusiek wat na die Tweede Wêreldoorlog gekomponeer is nie. Wanneer gaan ons wegkom van die standaardpraktyk om musiek te ontsluit wat net tot die verlede behoort? Dit is die taak van die musiekwetenskaplike om na die sin, samehang en betekenis in hierdie musiek te soek en wanneer hy in 'n onderrigsituasie staan, om hierdie sin, samehang en betekenis te ontsluit.

\subsection{Artistieke voorstelling van die werklikheid}

Die kunste kan die werklikheid nie op 'n akkurate, wetenskaplike wyse weergee nie. Kuns is ' $n$ interpretasie van die werklikheid omdat die kunstenaar daardie aspekte van die werklikheid weergee wat hy as relevant, belangrik of die moeite werd beskou. Vir die Middeleeuse kunstenaar was landskappe byvoorbeeld nie belangrik nie; daarom het hy dit nie uitgebeeld nie, al het hy daarin geleef (Hobbs \& Duncan, 1992:321).

In die twintigste eeu word minder kieskeurig met die werklikheid omgegaan met die gevolg dat die persepsie bestaan dat die hedendaagse werklikheid meer gebroke is as die werklikheid van die verlede. Hierdie pessimistiese beskouing van die wêreld en die menslike natuur het tussen 1900 en 1945 neerslag gevind in uitgangspunte van die Modemistebeweging in die beeldende kunste.

If the cosmos is fractured and fragmented, if life is chaotic and meaningless, if the self is a congeries of irrational and uncontrollable impulses, art must reflect this broken and disharmonious reality. ... The Modernists sought to create an art that would embody and communicate their disturbing perception of reality as fractured and chaotic, or at best paradoxical. Reflections of this perception can be discerned in the Cubism of Picasso and Braque, the complex rhythms of Stravinsky and the atonality of Schoenberg, and the enigmatic and threatening world of Kafka's stories. In part at least, the restless experimentation so characteristic of Modernist artists, is the reflection of their ceaseless efforts to make their art an accurate image of their world view (Hobbs \& Duncan, 1992:399).

Wanneer Alban Berg se ekspressionistiese opera, Wozzeck, open met die soldaat, Wozzeck, wat besig is om die kaptein te skeer, word die situasie op die 
Bertha Spies

oog af geïnterpreteer as ' $n$ ondergeskikte in diens van sy meerdere. Na die afloop van die opera is dit egter duidelik dat hierdie oënskynlik onskuldige situasie dalk 'n dieperliggende betekenis kan hê, naamlik as 'n simboliese voorstelling van die underdog wat ten spyte van sy magtelose situasie tog die mes teen die keel van sy heerser het. In die loop van die opera word Wozzeck geestelik afgetakel deur die geleerde dokter wat hom as proefkonyn uitbuit (die betaling was nodig vir die onderhoud van sy minnares en sy buite-egtelike kind) en uitgetart deur die flambojante en bepluimde tamboermajoor wat Wozzeck se Marie afrokkel. Vir hom was daar net een uitweg uit hierdie dilemma en dit was om Marie se lewe te neem - met ' $n$ mes. Dieselfde mes is egter ook die oorsaak vir Wozzeck se dood wanneer hy, in die soeke na die mes wat hy in die meer ingeslinger het, self verdrink.

Gekomponeer in 1925, stel hierdie opera met sy anti hero inderdaad die werklikheid van die twintigste eeu voor, 'n werklikheid waarin geweld beskou word as die oplossing vir probleme en die selfvernietigende werking van sulke aksies gewoonlik nie geantisipeer word nie. Alhoewel dit 'n aangrypende opera is, en as een van die grootste werke van hierdie eeu beskou word (Dunsby \& Whittall, 1988:106), is die musiek volgens tradisionele siening nie "mooi" nie.

\subsection{Idealisering van die werklikheid}

Is dit dan nodig dat die kunste die gebroke werklikheid moet weergee? Is dit nie moontlik om ' $n$ ander, ideale (tonale?) werklikheid voor te stel nie? Die antwoord hierop is gewoonlik dat so 'n voorstelling nie eerlik is nie (Rookmaker, 1985:10). In die relatiwistiese tye waarin ons leef, is dit problematies om te verwag dat die kunste die waarheid moet weergee. Dit sou egter wel moontlik wees om te verwag dat die kunstenaar eerlik moet wees aangesien hy sý insig, sý visie en sý siening moet weergee. 'n Mens sou dus kon sê dat eerlikheid 'n manifestasie is van subjektiewe waarheid. $\mathrm{Al}$ gee die kunstenaar sy siening van die werklikheid weer, wat wel 'n geselekteerde werklikheid mag wees, en wel ook aspekte van die werklikheid wat almal nie aanstaan nie, toon dit tog aan "... how much life often is a tangle of good and bad things, of the evil and the positive ..." (Rookmaker, 1985:11).

Al bestaan die werklikheid dus uit "a tangle of good and bad things", is dit steeds relevant en volgens Bavinck nie in konflik met die Christendom nie (Wolters, 1992:8). Die werklikheid is nie pretensieus nie want dit is die wêreld waarin ons leef, die wêreld wat ons bestudeer en 'n wêreld wat aan God behoort (Botha, 1992:45). Al is alle aspekte van die werklikheid nie altyd die ideale terrein vir die beoefening van die kunste nie, is "beauty ... an expression of life" (Rookmaker, 1985:18). 
Die dilemma van die musiekwetenskaplike in die onderrigsituasie

Die idealisering van die werklikheid het in die verlede ook neerslag gevind in idealistiese beskouings wat gekoppel was aan Christelik-Nasionale ideologiee. Die gerigtheid op eie kultuur alleen het aanleiding gegee tot verskraalde sienings van die werklikheid met die gevolg dat die verskeidenheid van ons land se musiekkulture nie sy regmatige plek ingeneen het in die ontsluiting van die werklikheid nie.

Dit is egter nie net die musiekwerklikheid wat 'n probleem is vir die musiekwetenskaplike nie. Ook die ontsluiting daarvan is vir hom 'n probleem.

\section{Ontsluiting van die musiekwerklikheid}

In die studie van die werklikheid word nie alleen openbaar wat bestaan nie maar ook hoe dit bestaan (Van der Walt, 1992:124). Weens die omvattendheid en die gesofistikeerdheid van 'n studieterrein, in hierdie geval musiek, is dit onmoontlik om die volle, konkrete werklikheid op een slag te bestudeer. Daarom moet kante, fasette, aspekte, ensovoorts, van die werklikheid onttrek word om wette te vorm sodat insig in die struktuur van die werklikheid gevorm kan word. Dit beteken dat 'n seleksie van inhoud gemaak en toegangspoorte geskep moet word om moeilik verstaanbare inhoude te ontsluit. Albei hierdie aksies hou probleme in vir die musiekwetenskap omdat dit 'n negatiewe uitwerking het op die bekendstelling van die "volle werklikheid" (Spies, 1993:33-36). Die resultate van aksies soos die onttrekking van vakinhoud en die redusering daarvan tot didakties-geskikte elementarel ${ }^{l}$ word dikwels vanuit musiekwetenskaplike oogpunt beskryf as oppervlakkige veralgemenings en vereenvoudigings - resultate waarmee hy hom nie graag wil assosieer nie.

Die wyse waarop kante, fasette of aspekte van die musiekwerklikheid onttrek word, is dus vir die musiekwetenskaplike 'n probleem. Verder het die resultate van hierdie ontsluiting van die musiekwerklikheid ook aanleiding gegee tot fragmentasie van die vak wat weer negatief ingewerk het op die holistiese siening van musiek. Nie net is die studie van musiek opgebreek in ' $n$ teoretiese of 'n praktiese rigting nie - rigtings wat tradisioneel verteenwoordig is deur studie by universiteite en konservatoriums (Hochschule für Musik Detmold, p. 15 en Royal Northern College of Music Manchester, p. 6) maar die teoretiese studie van musiek is ook onderverdeel in subvakke soos musiekgeskiedenis en musiekteorie wat weer verder versplinter is. Gevolglik word aspekte van musiek, soos ritme, tempo, dinamiek, digtheid, toonkleur en register wat elkeen

1 Elementare is grond- of basisinsigte wat aan die leerling toegang verleen tot 'n bepaalde werklikheidsgebied. 
Bertha Spies

op sy eie nie "substansieel" genoeg is om 'n vakgebied te vorm nie, nie eintlik "bestudeer" nie.

'n Gefragmenteerde siening van byvoorbeeld die musiekteorie is vir dekades reeds ' $n$ bron van frustrasie vir musiekwetenskaplikes. In die sestigerjare skryf Rudolph Stephan (1967:6), vooraanstaande Duitse musiekwetenskaplike, byvoorbeeld in die program vir die kongres met die tema "Probleme van die musiekteoretiese onderrig" die volgende:

Die Einteilung des musiktheoretischen Unterrichts in verschiedenen Fächer, die einer längst vergangenen musikalischen Situation angemessen war, hat schon in den Zwanzigerjahren Kritik herausgefordert und als veraltet lebhafte Bedenken erregt.

[Die opbreek van die musiekteoretiese onderrig in verskillende vakke, 'n praktyk wat geskik was vir 'n vergange musikale situasie, is reeds in die twintigerjare gekritiseer en as verouderd bestempel.]

Hy meld verder dat die pogings om 'n "einheitliche Musiklehre" te skep, tot op daardie datum ook nie geslaag het nie en bepleit 'n grondige hersiening van musiekteoretiese onderrig.

Die tradisionele kompartementalisering binne die musiekteorie (in subvakke soos teorie, melodie, harmonie, kontrapunt, vorm) is 'n goeie voorbeeld van so 'n fragmentering van die musiek. Verder is die studie van musiektekstuur verskraal tot 'n studie van toonhoogte alleen sodat 'n konsep soos progressie in tonale teksture byvoorbeeld gereduseer is tot die studie van die opeenvolging van klankformasies. Parameters soos ritme, toonhoogte, dinamiek en register wat almal betrokke is by die skep van progressie word feitlik nooit in berekening gebring nie. Selfs by die studie van strukture speel toonhoogte steeds 'n prominente rol soos in die ontleding van byvoorbeeld die sonatevorm waar toonsoortverhoudings (tonika-dominantverhouding) gewoonlik die hoofaandag kry terwyl die dramatiese energie wat ontwikkel word deur die dinamiese ontplooiing van die opponerende musikale idees baie keer verwaarloos word.

'n Eendimensionele, atomistiese siening van die musiektekstuur met die klem op toonhoogte alleen het egter nie net die studie van die musiek van die verlede beperk nie maar ook die begrip en insig in twintigste-eeuse teksture gekortwiek omdat dit nie oorgedra kan word op nie-tonale (twintigste-eeuse) teksture nie. Die tradisionele wyse waarop musiekteksture bestudeer word, lewer 'n hoogs beperkende bydrae tot die ontsluiting van hedendaagse teksture waar toonhoogte, toonduur, ritme, tempo, dinamiek, digtheid, toonkleur en register op hoogs geïntegreerde wyse op mekaar inwerk. 
Die dilemma van die musiekwetenskaplike in die onderrigsituasie

\section{Gevolge van 'n gefragmenteerde musiekwerklikheid}

Die verskillende fasette van die musiek as studieterrein het so gespesialiseerd geraak dat die veld versplinter het tot losstaande velde van ondersoek waar musiekwetenskaplikes al hoe meer weet van al hoe kleiner areas. Vir die musiekwetenskaplike word dit al moeiliker om byvoorbeeld die terrein van twintigste-eeuse musiek as geheel te beheers. Die probleem is nog groter as 'n musiekopvoedkundige hierdie musiek moet ontsluit. Dapper pogings van musiekopvoedkundiges om holistiese sienings van hedendaagse musiek te bevorder, word dikwels afgemaak as "musiekwaardering" vir die leek.

Enkele gevolge van die fragmentering van die musiek word vervolgens bespreek.

\subsection{Negatiewe uitwerking op die studie van hedendaagse musiek}

Een gevolg van die gefragmenteerde en verskraalde visie van die musiekwerklikheid is dat studente en selfs opgeleide musici twintigste-eeuse musiek nie verstaan nie terwyl ons reeds op die drumpel van die een-en-twintigste eeu staan (Reitan, 1992:625).

Die feit dat die ordeningsbeginsels in die hedendaagse musiek beoordeel word vanuit die perspektief van die kanon, naamlik vanuit tonale wetmatighede, en dat ordeningsbeginsels binne een musiekstyl oorgeplaas word op 'n ander musiekstyl, versterk die persepsie dat hedendaagse musiek nie sin maak nie. Weens die afwesigheid van tradisionele toonhoogte-ordeningsbeginsels in hierdie musiek, is dit dus geen wonder nie dat die tradisioneel-opgeleide musikus nie in staat is om hierdie musiek te verstaan of vir ander te kan ontsluit nie.

Die persepsie bestaan dat die ontoeganklikheid van hedendaagse musiek toegeskryf kan word aan die afwesigheid van wetmatighede in hierdie musiek die afwesigheid van sintaksis, sin en samehang. Tersaaklike navorsing en artikels oor twintigste-eeuse musiek het egter bewys dat ordeningsbeginsels in hierdie musiek wel teenwoordig is (Forte, 1973:223-224; Cook, 1987:294-371; Dunsby \& Whittall, 1988:154-207). Die afleiding wat dus gemaak kan word, is dat die wyse waarop hierdie inligting oorgedra word, nie toeganklik is nie of selfs dat hierdie tipe inligting verdere ontsluiting noodsaak.

\subsection{Ontoeganklikheid van gespesialiseerde tekste}

Die musiekwetenskaplike wat verantwoordelik is vir die soeke na sin, samehang en betekenis in hedendaagse musiek, werk op so 'n vlak dat hy feitlik net vir homself skryf. Die gevaar van "privaat tale" en die negatiewe invloed wat 
dit op die ontsluiting van die vak het, is wesenlik. "Music theory ... is a process of discourse. If those engaged in a discourse are not to end up talking each to himself, dissolving the discourse into monadic mutterings, certain hermeneutic principles enforce themselves" (Rahn, 1989:143). Hedendaagse musiek is ontoeganklik omdat hermeneutiese aksies ten opsigte van alien texts óf nie bestaan nie óf nie effektief uitgevoer word nie, hoofsaaklik weens die bestaan van "privaat tale" en/of monadic mutterings.

\subsection{Eensydige siening van die musiekwerklikheid}

'n Eensydige siening van die musiekwerklikheid het onder andere ook aanleiding gegee tot die negering van die verskeidenheid musiekkulture in ons land. Hierdie onbegrip vir mede-landsburgers se musiekkulture en die belangrike rol wat musiek binne gemeenskappe op sosiale vlak speel, is nie bevorderlik vir goeie verhoudings met mense buite die eie kultuurgemeenskap nie.

\subsection{Gebrekkige kpmmunikasie tussen spesialiste}

Die fragmentering van die musiek as vakdissipline gee verder aanleiding tot gebrekkige of geen kommunikasie tussen spesialiste binne die professie. Die veronderstelde onversoenbaarheid van die akademiese en die professionele benadering tot musiekstudie en die ongelukkige stereotipering wat daarmee gepaard gaan, het byvoorbeeld 'n lang geskiedenis. ("'n Akademiese loopbaan word gekies as die persoon nie goed genoeg klavier, of watter instrument ook al, kan speel nie" teenoor "'n professionele loopbaan word gekies as die persoon nie slim genoeg is nie.") Hierdie eensydige siening het nadelige gevolge vir die noodsaaklike interaksie tussen die akademie en die professie soos hieronder aangetoon sal word.

Weens die gespesialiseerde aard van 'n akademiese en 'n professionele loopbaan, gebeur dit selde dat akademiese en professionele kennis en vaardighede in een persoon gesetel is. Dit beteken dat die twee rigtings langs mekaar in 'n soort "treinspoor"-situasie bestaan, waar interaksie tussen die twee professies ontbreek. Die situasie kan geillustreer word deur 'n aanhaling uit die veertigerjare te vergelyk met ' $n$ aanhaling uit die negentigerjare.

Glen Haydon (1941:189) noem in 'n standaardwerk oor musiekwetenskap as eerste "principle of teaching" dat die musiekonderwyser op hoogte moet wees van die basiese doelstellings van "teaching". Hy gaan dan voort om twee duidelike standpunte in hierdie verband te omskryf.

One view is that the function of education is to bring the pupil up to the standards of the society in which he lives. The educational program that serves this purpose is designed chiefly in terms of what it is essential for the 
Die dilemma van die musiekwetenskaplike in die onderrigsituasie

child to know. A second view is that the function of education is to develop the child in aptitudes most satisfying to him, but at the same time valuable to society. This conception of education motivates the so-called 'child-centred' school.

Feitlik 'n halfeeu later verwys Jane Atkinson (1990:40-41) van die Fakulteit Opvoedkunde aan die Universiteit van Brits-Kolumbië in Kanada na die "nuwe" paradigma in die onderwys, naamlik 'n benadering waarin die leerling 'n aktiewe rol speel in die onderrigsituasie. As plaasvervanger vir die tradisionele outoritêre, outokratiese, rigiede, vakgerigte benadering, ondersteun Atkinson die "humanizing of education" (1990:39) onder andere deur 'n meer buigbare struktuur en ' $n$ meer buigbare benadering tot die onderwys waarin kennis in konteks bestudeer word. Volgens hierdie "nuwe" paradigma word leer gesien as 'n proses en nie 'n produk nie. Sy glo dat onderwys 'n tweerigtingverkeer moet wees waarin onderwyser en student nie as rolle gesien word nie maar as mense.

Wanneer hierdie "nuwe" paradigma vergelyk word met die tweede siening in Haydon se aanhaling, is dit duidelik dat hy hierdie ontwikkeling vyftig jaar vroeêr reeds voorsien het. Die vraag kan met reg gevra word hoe dit moontlik is dat soveel jare verby gegaan het sonder dat kennis geneem is van die idee van Haydon, 'n internasionaal hoog aangeskrewe musiekwetenskaplike. Hoekom het Haydon se mensgerigte siening ten opsigte van die opvoedkunde nie in die musiekopvoedkunde gerealiseer nie?

\section{Voorstelle vir die oplossing van die musiekweten- skaplike se dilemma}

In hierdie artikel is nie aandag gegee an die frustrasie wat algemeen voorkom by akademici wat die dubbelrol van navorser en onderwyser moet vervul nie. In die geval van die musiekwetenskaplike word die frustrasie verhoog deur botsende doelstellings van die opvoedkunde en die musiekwetenskap. Die enkele voorstelle wat hieronder volg, moet gesien word as 'n poging om nuwe perspektiewe op die probleem te verskaf.

\section{- 'n Realistiese siening van die musiekwerklikheid}

Indien die musiekwetenskaplike kan anvaar dat die musiekwerklikheid vele kante en fasette het, dat ligte musiek byvoorbeeld 'n beduidende snit van die musiekwerklikheid uitmaak en dat nie-Westerse musiek deel is van die werklikheid in ons land, sal hy vind dat nuwe velde vir navorsing beskikbaar word. Die aard van hierdie tipe navorsing sal vanselfsprekend verskil van die navorsing waaraan hy gewoond is aangesien dit waarskynlik van interdissiplinêre aard en meer kontekstueel gerig sal wees. Al stel interdissiplinêre 
Bertha Spies

studies hoë eise aan die vakspesialis (omdat ander vakgebiede as die eie vakgebied betrek word), sal die resultate daarvan waarskynlik meer relevant wees vir die wêreld en die gemeenskap waarin ons leef.

\section{- Ontsluiting van ontoeganklike tekste}

Dit is die musiekwetenskaplike se taak om die sin en betekenis in musiekstrukture te vind en bloot te lê maar ook om seker te maak dat die boodskap op so 'n wyse oorgedra word dat dit verstaanbaar is. 'n Vakgebied kan op 'n evolusionêre wyse dinamies ontwikkel indien 'n hermeneutiek vir ontoeganklike tekste gevind kan word.

\section{- Kritiese beoordeling van oorgelewerde tradisies}

As akademikus is dit ook die musiekwetenskaplike se verantwoordelikheid om krities te kyk na onderrigstrategiee wat gebaseer is op sakrosankte teorieë soos dié van Fux, Rameau en selfs Riemann. Alhoewel sulke teorieë histories en musiekwetenskaplik vantbelang is, is alle aspekte daarvan nie altyd didakties effektief nie. Baie probleme in die onderrig van musiekteorie is te wyte aan rigiede denkwyses en strategieē wat deur die loop van eeue gekanoniseer is.

\section{Slot}

Die mens kan die werklikheid nie eintlik verander nie want dit is 'n gegewe. Wat die mens wel kan doen, is om te probeer om hierdie werklikheid beter te verstaan. Die musiekwetenskaplike het dus 'n dubbele opdrag, naamlik om die sin, samehang en betekenis in die musiekwerklikheid as geheel te soek en indien hy wil verseker dat die akademiese tradisie voortgesit word, dit op so 'n wyse te ontsluit dat dit ook vir die leerder sin maak.

\section{Bibliografie}

ATKINSON, J. 1990. A Practical Look at the New Paradigms of Education. (In Dobbs, J.P.B. ed. Music Education: Facing the Future: Proceedings of the 19th World Conference of the International Society for Music Education held in Helsinki, Finland. London : ISME. p. 39-42.)

BOTHA, M.E. 1992. 'n Wêreld wat aan God behoort: inleiding in 'n Christelike werklikheidsleer (Ontologie). Potchefstroom : PU vir CHO. (D 3/92.)

CHEW, G. 1992. Culture and Value: the Musical Canon in a 'New South Africa'. Suid-Afrikaanse Tydskrif vir Musiekwetenskap, 12:1-10.

COOK, N. 1987. A Guide to Musical Analysis. London: Dent.

DUNSBY, J. \& WHITTALL, A. 1988. Music Analysis in Theory and Practice. New Haven : Yale University Press. 
FORTE, A. 1973. The Structure of Atonal Music. New Haven : Yale University Press.

HAYDON, G. 1941. Introduction to Musicology: A Survey of the Fields, Systematic and Historical, of Musical Knowledge and Research. Chapel Hill : University of North Carolina Press.

HEIMES, K. 1989. The Soft Constitution of the Musical Object. Paper read at the eighth conference on Ethnomusicology. Durban-Westville.

HOBBS, J. A. \& DUNCAN, R.L. 1992. Arts in Civilization: Pre-historic Culture to the Twentieth Century. London : Prentice-Hall.

HOCHSCHULE FUR MUSIK DETMOLD VORLESUNGSVERZEICHNIS 1994/95. 1994. Detmold : Hochschule für Musik Detmold.

LODEMANN, W. 1994. Effective Music Education in South Africa: a Critical Reply. Suid-Afrikaanse Tydskrif vir Musiekwetenskap, 14:123125.

MITCHELL, D. 1963. The Language of Modern Music. London : Faber.

POLANSKY, L. 1991. 17 Gloomy Sentences (and Commentary) at the Turn of the Millenium (in the Form of an Editorial). Leonardo Music Journal, 1(1):17-18.

RAHN, J. 1989. Notes on Methodology in Music Theory. Journal of Music Theory, 33(1):143-153.

REITAN, L. 1992. Does It Really Mean Anything? Some Aspects of Musical Meaning. (In Paynter, J. et al. Companion to Contemporary Musical Thought, vol. 2, London : Routledge. p. 625-633.)

ROOKMAKER, H.R. 1985. Christianity and Art. Potchefstroom : PU vir CHO. (Instituut vir Reformatoriese Studie. Studiestuk nr. 210.)

ROYAL NORTHERN COLLEGE OF MUSIC. 1995. Prospectus for Year of Entry: 1996. Manchester : Royal Northern College of Music.

SPIES, B.M. 1993. Die reduksie van inhoud by die onderrig van musiekteoretiese vakke. Musicus, 21(1): 33-36.

STEPHAN, R. red. 1967. Probleme des Musiktheoretischen Unterrichts. Berlin : Merseburger.

THOMPSON, W. 1987. Resensie van 'Counterpoint in the Style of J. S. Bach' by Thomas Benjamin. Journal of Music Theory, 31(2):345-353.

TIME MAGAZINE. 1995. 6 Februarie.

VAN DER STOEP, F. \& LOUW, W.J. $1990 . \quad$ Inleiding tot die didaktiese pedagogiek. Pretoria : Academica.

VAN DER WALT, B.J. 1992. Venster op die werklikheid: 'n reformatoriese lewensvisie-filosofie-wetenskap. Potchefstroom : PU vir CHO. (DSPpublikasies, nr. 13.) 
Bertha Spies

WOLTERS, A.M. 1992. Creation Order: an Historical Look at Our Heritage.

(Referaat gelewer in Toronto in Junie 1992 en in Augustus 1993 by die IRS-konferensie, PU vir CHO.) 
